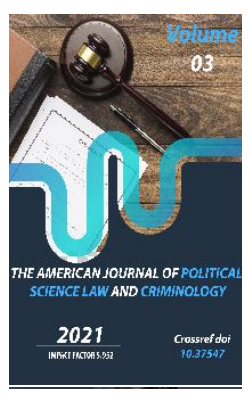

\title{
Issues Of Social Protection Of Children With Disabilities In The Context Of Inclusive Education In Uzbekistan
}

Bekjon Salihovich Ismoilov

Independent Applicant, Tashkent State Law University, Uzbekistan

Journal Website: http://usajournalshub.c

om/index,php/tajpslc

Copyright: Original content from this work may be used under the terms of the creative commons attributes 4.0 licence.

\section{ABSTRACT}

The article analyzes the issues of social protection of children with disabilities in Uzbekistan on the example of inclusive education, legal and regulatory documents adopted in this area, as well as the created conditions.

\section{KEYWORDS}

State, society, disability, social protection, inclusive education, renaissance, disability, category, children.

\section{INTRODUCTION}

Today, building a strong civil society and a democratic state based on the rule of law is one of the most important challenges facing our government. We know that countries with strong civil societies have a strong future and stable governance. Undoubtedly, the basis of the future of such a strong state today and tomorrow will be spiritually rich, physically 
mature and spiritually active youth. As President Sh.M. Mirziyoyev, "a decisive role in the development of any society is played by the healthy and harmonious development of the younger generation, on which the future of this society depends. That is why we believe that our energetic, proactive, well-developed young people with modern knowledge and skills will support us in expanding our reforms and making them more effective. "We consider the family, preschool education, school and higher education, as well as scientific and cultural institutions as the most important links in the future Renaissance [1].

\section{METHODS}

The article includes data studied on the basis of generally accepted analytical methods. Also, the issues of social protection of children with disabilities in Uzbekistan on the example of inclusive education, legal and regulatory documents adopted in this area and the created conditions were analyzed.

\section{RESEARCH RESULTS}

Indeed, youth is the trust and support of the state in all reforms in our country. In this sense, improving the quality of education, which plays an important role in determining the future of young people, is one of the most pressing problems of our time. Reforms to improve the quality of education, including the education of children and young people with disabilities, play an important role in building a strong future for children with disabilities. Here is the official definition of a child with a disability: a child with a disability is a person in need of social assistance, protection due to limited physical activity due to physical, mental, sensory (sensory) and / or mental impairments. the child is recognized as a disabled person in accordance with the procedure [2].

It is noteworthy that the positive changes taking place in this area make a significant contribution to the development of inclusive education. Speaking about the social protection of children with disabilities, it should be noted that the legal provision of their education in comfortable conditions is a priority. Children in need of social protection are children who, due to the current situation, are in difficult living conditions in need of special protection and support from the state and society, including:

Children with disabilities;

Had physical and (or) mental developmental disabilities [2].

It is no secret that all students want to study in secondary schools, living with their families. Unfortunately, children with disabilities practically do not have such opportunities in practice. This shows that the right to education of children with additional needs is not exercised on the basis of free choice. Therefore, it would be correct to call inclusive education a form of social protection for children with disabilities. Inclusive education is a special educational process that ensures that children with disabilities receive education in general education schools. Article 20 of the new edition of the Education Law provides a formal definition of the concept of inclusive education. According to him, "inclusive education aims to provide all students with equal opportunities to study in educational institutions, taking into account the needs of individual learning and a variety of individual opportunities. Inclusive education is provided in educational institutions for children with 
physical, mental, sensory or mental disabilities. The organization of inclusive education is determined by the Cabinet of Ministers of the Republic of Uzbekistan [3].

Speaking about inclusive education, Oybek Isakov, chairman of the Association of Persons with Disabilities of Uzbekistan, member of the expert council of the Senate Committee on Science, Education and Health, said:

"Inclusive education is ensuring equal access to education for all students, taking into account special educational needs and differences in individual abilities" [4].

If you look at the history of the development of education for children with disabilities, you can see that they were educated in the form of specialized boarding schools. At first glance, this is a very favorable social environment for the education of children with special needs. However, boarding school has its advantages and disadvantages. The positive aspects are mainly reflected in ensuring their right to education. That is, they receive the kind of education that suits them. Boarding schools have special facilities for children with disabilities to make them feel at ease. As a result, the same number of disabled children attend these institutions. This is an important factor in the good upbringing of such children. The downside is that they are isolated from a healthy society. This is a serious obstacle to the adaptation of children with disabilities to a normal social environment after leaving boarding school. Being away from family from an early age can lead to psychological depression. Self-service capability is also not in the expected standard state. Recently, in order to fully express the rights of children with disabilities, attention to inclusive education in our country has increased significantly. We believe that developing inclusive education will help children with disabilities adapt to society without undue barriers. In a sense, the immunity of society to the acceptance of such people is greatly enhanced. Unfortunately, this form of education in our country does not have its own development methodology. This process can be assessed objectively. Because the process of inclusive education is new to our national education system. However, the fact that this is a new approach should not lead to a drop in attention. Perhaps one of the main tasks should be to improve the conceptual preparation of children with disabilities for general education. Of course, bringing these processes in line with legal requirements is not an easy task. This is due to the fact that a number of tasks will be given a priority, for example, solving integration issues for teaching children with special needs in general education schools, updating the material and technical support of an educational institution. We believe that when addressing such issues, it is important to pay attention to the following aspects.

1. Development of special programs aimed at creating a clear picture of the disability of children with disabilities in healthy children; This is mainly done in order to establish the right relationship between students and children with additional needs.

2. Formation of the ability of teachers to work with children with disabilities on the basis of special methods; it aims to enhance the ability of professionals to work with students in this situation.

3. Organization of comprehensive medical and pedagogical assistance in secondary schools. 
On the whole, this issue is in the center of attention of the world community. Because in the world, inclusive education has become one of the fastest growing forms of education in recent years. In this sense, the Conventions on the Rights of the Child and international agreements are leading in this regard. States Parties recognize the child's right to education and ensure the progressive realization of this right on an equal basis, including:

- Introduce free and compulsory primary education;

- $\quad$ Encourage the development of various forms of secondary education, both general and vocational, ensure that all children receive such education, and introduce free education and, where necessary, financial support. take the necessary measures, such as assistance;

- $\quad$ By all necessary means to ensure that every child receives a higher education to the best of his ability;

- $\quad$ Provide all children with access to information and materials in education and vocational training;

- $\quad$ Take steps to help children attend school regularly and to reduce dropout rates.

States Parties shall take all appropriate measures to ensure that school discipline is respected in accordance with the human dignity of the child and in accordance with this Convention.

The participating States shall develop international cooperation on issues related to education, including those aimed at eradicating ignorance and illiteracy throughout the world and facilitating access to scientific and technical knowledge and modern teaching methods. In this regard, particular attention should be paid to the needs of developing countries. The participating States agree that the education of the child should take place in the following areas:

- Full development of the child's personality, talents, mental and physical abilities;

- Promoting respect for human rights and fundamental freedoms and the principles enshrined in the Charter of the United Nations;

- To educate in the child respect for his parents, his cultural identity, language and values, national values of the country in which the child lives, the country where he was born, a level of cultural development that differs from his own;

- To prepare the child for a free society in the spirit of peace, tolerance, equality between men and women and friendship between all peoples, ethnic, national and religious groups, as well as between indigenous peoples;

- Including respect for the environment.

None of the provisions of this article or article 28 shall provide for the establishment of educational institutions for individuals and organizations and their leadership in accordance with the principles set out in paragraph 1 of this article, as well as the minimum education provided by such educational institutions, is not interpreted as restricting freedom to comply with the requirement that it must comply with standards [5].

The essence of this rule is that children with special needs, like other healthy peers, should be able to attend secondary school. Creation of these opportunities requires really a lot of financial security. Adapting educational 
institutions to the needs of children with disabilities, especially healthy ones, is a complex process. To be able to realistically assess the situation, let's approach the situation based on a certain complexity. We know that educational institutions in our country are multi-storey, and children with disabilities who move in wheelchairs or crutches cannot use this staircase on their own. At the same time, we must openly admit that most mainstream schools do not have lifts. In addition, classroom and laboratory chairs and equipment were not tailored to the subjective needs of students with special needs.

Not all general education schools are equipped with special projectors that enlarge fonts and pictures for children with visual impairments. This process is explained, on the one hand, by the fact that this form of education is less practical in our country, and on the other hand, by the unsatisfactory material and technical support of educational institutions. A number of positive steps are being taken in our country to develop special education. In particular, the development of flexible educational programs for children in need of physical assistance;

- Monitoring the implementation of the developed programs at the state level;

- Optimization of the process of working with certain categories of children on the basis of additional benefits, bonuses;

- Improving the quality of textbooks for children in need based on national educational standards;

- This includes expanding partnerships with international organizations specializing in working with children with disabilities.

In short, the goal of inclusive education is to ensure and ensure that children with disabilities also receive effective education in public schools. In our opinion, the following measures are priority for the effective organization of special education in our country. Initially, it is desirable to develop the necessary scientific skills in the form of inclusive education among educators. The fact that these processes are carried out on the basis of national conferences and international conferences with the participation of public education authorities ensures the seriousness of approaches in this area. To create a medicalpsychological-pedagogical commission to identify children with developmental disabilities in conjunction with the regional department of the Ministry of Public Education. The identification of children with disabilities (3-7 years old) for the purpose of learning in joint groups and classes plays an important role in the development of inclusive education. The importance of the issue here lies in the fact that the placement of children with disabilities with early detection in an educational institution requires medical and psychological vigilance. This is due to the fact that today our national educational standards lack sufficient methodological recommendations, teaching aids, and industry programs for teaching this category of children in general education schools and ensuring their effective education. One area that should be considered is the development of criteria for assessing their performance in secondary school. Inclusive Education Centers under the Ministry of Public Education are now working to address these issues.

The main activities of such a center are: Implementation of inclusive education in the education system of the Republic of Uzbekistan by organizing various conferences and trainings for teachers and educators 
working in the field of education for children with disabilities;

- Development of textbooks for children with disabilities;

- Creation of experimental sites for children with disabilities;

- Development of a separate development plan for the child;

- Provision of consulting services to teachers and parents;

- Development of guidelines, recommendations, plans for working with children with disabilities in special schools;

- providing information on legal activities and social protection;

- Cooperation with public and state organizations working in the field of education of children with disabilities;

- Coverage of existing shortcomings in the education of children with disabilities in the media;

- Cooperation with international organizations;

- Introduction of experience in the field of special education.

In general, one of the most important tasks of inclusive education in our country is to provide comprehensive support to children with disabilities and thus adapt them to a healthy society. In this regard, in 2001, the Republican Center for Inclusive Education established the Center for Inclusive Education Resource in cooperation with UNESCO. The tasks of this center are as follows. promoting the organization of education for children with disabilities who are not involved in education;

- Providing inclusive classrooms and groups with teaching materials;
- Providing practical and methodological assistance to local resource centers;

- Organization of various activities, counseling for parents of children with disabilities on the upbringing of their children, preparation for school and social life;

- Establishment of inclusive classes and groups in secondary schools for the purpose of education of children and adolescents with disabilities, vocational training, integrated education, etc.

In conclusion, it should be noted that everyone has the right to education [6].

In this regard, in accordance with the Decree of the President of the Republic of Uzbekistan dated April 29, 2019 No PF-5712 "On approval of the Concept of development of public education in the Republic of Uzbekistan until 2030" Development of education, improvement of the education system for children with special educational needs and improving the quality of educational services provided to them is becoming one of the most important issues of the education system. In order to ensure free education of children with disabilities in secondary schools, the concept of developing inclusive education in the public education system for 2020-2025 was adopted. The application of the concept to the lives of children with physical disabilities serves their social integration. The concept will be implemented in two stages, including:

a) During the period from 2020 to 2022:

The regulatory framework in the field of inclusive education will be improved;

Qualified teachers will be trained, retrained and retrained for the inclusive education system; 
The material and technical base of institutions with inclusive education will be strengthened, they will be provided with special devices (lifting devices, ramps, handrails, etc.), the necessary literature, manuals, equipment for training in various professions ;

Modern information and communication technologies and innovative projects will be introduced in the field of inclusive education;

The right to education of children with special educational needs, the formation of a positive social environment among the population by explaining the essence of inclusive education;

Measures will be taken to discriminate against children with special educational needs and to prevent them from being abused;

The system of inclusive education will be introduced on a pilot basis in the activities of individual educational institutions;

b) From 2023 to 2025:

The system of inclusive education will be gradually introduced in other general secondary schools;

Measures will be taken to ensure the right of every child with special educational needs to inclusive education;

Teaching methods in inclusive education will be improved and the principles of individualization will be gradually introduced into the educational process;

In the process of inclusive education, measures are taken to educate students spiritually and morally, to form them physically healthy and strong;

Specialized state educational institutions (schools and boarding schools) for children with special educational needs based on the physical and mental needs of students and the geographical location of educational institutions (hereinafter - specialized educational institutions) number is optimized [7].

From the academic year 2021/2022:

Education of children with special educational needs in primary correctional classes is based on adaptive curricula;

special pedagogical staff units will be allocated through the gradual optimization of the staff of specialized educational institutions in secondary schools with an inclusive education system for children with special educational needs and the opening of basic correctional classes;

In order to develop the potential of children with special educational needs, secondary schools with an inclusive education system may develop individual curricula for these students with the participation of them and their parents (legal guardians);

Special educators and tutors (assistant pedagogical staff) closely assist children with special educational needs in mastering individual educational programs;

Volunteers with appropriate qualifications as tutors (assistant pedagogical staff) and senior students in the field of pedagogy of higher education institutions are involved in the inclusive education system on a voluntary basis during the pedagogical practice. one of the parents (their legal representatives) of children with special educational needs is included in the Supervisory Board of secondary schools where the system of inclusive 
education has been introduced and basic correctional classes have been opened;

Based on the needs of persons with disabilities, up to two percent of the total state enrollment rate for vocational education institutions is allocated to these persons;

The calculation of salaries of teachers who teach students individually at home is carried out in accordance with the procedure developed by the Ministry of Public Education and the Ministry of Finance.

\section{CONCLUSIONS}

Summarizing the above, it can be concluded that the protection of children's rights in our country is carried out at the level of state policy. As a logical follow-up to this idea, it is appropriate to cite the main directions of state policy in this area. State policy on protection of the rights of the child The main directions of the state policy on protection of the rights of the child are:

- Ensuring the rights, freedoms and legitimate interests of the child;

- Protection of life and health of the child;

- Not to discriminate against the child;

- Protection of the honor and dignity of the child;

- Ensuring equal rights and opportunities for children;

- Improving the legal framework for the guarantees of the rights of the child;

- Ensuring compliance with the documents;

- Ensuring openness and transparency of the activities of state bodies and their officials to ensure and protect the rights, freedoms and legitimate interests of the child;
- To promote the physical, intellectual, spiritual and moral development of children;

- Training, advanced training and retraining of personnel working in the field of protection of children's rights;

- Fostering in children a sense of patriotism, citizenship, tolerance and peace;

- To acquaint the child with the historical and national traditions, spiritual values and achievements of world culture of the people of Uzbekistan;

- Development of the child's personality, his scientific, technical and artistic creativity;

- Support for children's initiatives;

- Formation of legal consciousness and legal culture in the child;

- Cooperation between government agencies and non-governmental non-profit organizations to ensure the rights of the child;

- Development of cooperation with international organizations working in the field of protection of children's rights;

- Assistance in children's social skills, reduction of juvenile delinquency [8]. It is important to note that when the lives and futures of children and young people are taken into account, the history of that country is strong and its future is great.

\section{REFERENCES}

1. Speech of the President of the Republic of Uzbekistan Shavkat Mirziyoyev at the Youth Forum of Uzbekistan. 26.12.2020

2. Law of the republic of Uzbekistan on guarantees of the rights of the child 3-M.

3. Law of the republic of Uzbekistan on education 23.09.2020 20-m.

4. From the article by Dilmurod Yusupov, PhD student, Institute for Development 
The American Journal of Political Science Law and Criminology (ISSN - 2693-0803)

Published: April 24, 2021 | Pages: 29-37

Doi: https://doi.org/10.37547/tajpslc/Volume03Issue04-05

Studies, University of Sussex,

UK.Gazeta.uz

5. Convention on the Rights of the Child 29-

M.

6. Article 41 of the Constitution of the Republic of Uzbekistan.

7. About measures for further improvement of system of education of children with special educational needs Resolution .13 .10 .2020

8. Law of the republic of Uzbekistan on guarantees of the rights of the child 4-M. 07.01 .2008 